\title{
PROFILE OF SECONDARY GLAUCOMA AT A TERTIARY HOSPITAL IN EAST JAVA
}

\author{
Evelyn Komaratih, Yuyun Rindiastuti, Yulia Primitasari \\ Department of Ophthalmology, Universitas Airlangga/Dr. Soetomo Hospital, Surabaya, Indonesia
}

\section{ABSTRACT}

\begin{abstract}
Glaucoma is the leading cause of irreversible blindness. The aim of this study was to review the profile of secondary glaucoma cases visiting a tertiary hospital in East Java. This is retrospective observational study, completed case records of new patients with secondary glaucoma who presented to glaucoma clinic from January 2014 to April 2016 were included. Out of the 363 case records screened, 66 cases were found to eligible for inclusion. The evaluation included a detailed history and examination performed including vision, anterior segment examination, intraocular pressure (IOP), gonioscopy, and fundus evaluation. Diagnosis of secondary glaucoma was made on the basis of presence of a secondary cause for presence of raised IOP. 66 cases were eligible for inclusion in the study, most of the cases was occurred in the range age 21-50 years. The male female ratio was 1.3:1. Frequent causes of secondary glaucoma were lens factor $30.8 \%$, steroid induced $29.5 \%$, uveitic $20.5 \%$, neovascular $15.4 \%$, and surgical complication 3.8\%. Most patients with secondary glaucoma have poor vision $<0.1$ with high IOP at presentation. Assessment and early detection of underlying cause is the key guide to treatment strategy.
\end{abstract}

Keywords: Secondary glaucoma; glaucoma; tertiary center; intra-ocular pressure

\section{ABSTRAK}

Glaukoma adalah penyebab utama kebutaan yang tidak dapat disembuhkan. Tujuan dari studi ini adalah untuk meninjau profil kasus glaukoma sekunder di rumah sakit tersier Jawa Timur. Studi ini merupakan studi observasi restrospektif dari rekam medis lengkap pasien baru dengan glaukoma sekunder yang datang ke poliklinik glaukoma antara Januari 2014 sampai April 2016. Dari 363 rekam medis, terdapat 66 rekam medis yang memenuhi syarat inklusi. Evaluasi termasuk data riwayat yang terperinci dan pemeriksaan tajam penglihatan, segmen anterior, tekanan intraokular (TIO), gonioskopi dan fundus. Diagnosis glaukoma sekunder dibuat berdasarkan adanya penyebab sekunder yang menyebabkan peningkatan TIO. Terdapat 66 kasus yang memenuhi syarat inklusi studi ini, dan didapatkan kasus terbanyak terjadi pada rentang usia 21-50 tahun. Rasio pria dan wanita adalah 1.3:1. Penyebab terbanyak dari glaukoma sekunder adalah faktor lensa $30.8 \%$, induksi steroid $29.5 \%$, uveitis 20.5\%, naovaskular 15.4\% dan komplikasi tindakan bedah 3.8\%. Kebanyakan pasien dengan glaukoma sekunder mempunyai tajam penglihatan yang buruk < 0.1 dengan TIO yang tinggi saat pertama kali datang. Penilaian dan deteksi awal penyebab yang mendasari adalah kunci utama untuk strategi perawatan.

Kata kunci: Glaukoma sekunder; glaukoma; pusat tersier; tekanan intraokular

Correspondence: Evelyn Komaratih, Department of Ophthlamology, Universitas Airlangga, Mayjen Prof. Dr. Moestopo No 6-8, Surabaya, Indonesia. Phone: +628123206002. E-mail: risetpublikasi@ gmail.com

pISSN:2355-8393 • eISSN: 2599-056x • doi: 10.20473/fmi.v56i1.18452

- Fol Med Indones. 2020;56:56-59 • Received 13 May 2019• Accepted 14 Nov 2019

- Open access under CC-BY-NC-SA license • Available at https://e-journal.unair.ac.id/FMI/

\section{INTRODUCTION}

Glaucoma is one of the most common neuropathies of the optic nerve. It causes progressive atrophy of the optic disc resulting in typical defects in the visual field. It can lead to total loss of vision if left untreated. Glaucoma is the leading cause of irreversible blindness worldwide, and the second most common cause of blindness after cataracts (Congdon et al 2004, Tham et al 2014, Wang et al 2010). It is estimated that more than 60.5 million people worldwide are threatened by glaucoma and this number tend to reach 79.6 million by 2020 (Yamanaka et al 2015, Masompour et al 2016).

In recent years, there has been a rapid emergence of population-based studies in Asia, providing an opportunity to allow better estimation of global glaucoma prevalence. Considering Asia represents approximately $60 \%$ of world population, data from contemporary Asian studies may provide an estimation of global glaucoma prevalence (Gadia et al 2008, Ramakrishnan et al 2004). However, Indonesia still lacks of epidemiologically valid data on various 
subtypes of glaucoma. Given the large geography and ethnic diversity, the pattern of glaucoma is bound to vary in different regions of Indonesia. Despite its public health significance, there is limited data available on the prevalence of secondary glaucoma and the possible risk factors for secondary glaucoma. There was $0.2 \%$ of glaucoma related blindness according to National survey of Indonesian ministry from 1993 to 1996. Rifqah et al (2017) reported 63 cases of secondary glaucoma in top referral eye hospital in West Java within one year with among of these cases were related to lens induced glaucoma. East Java is one of the regions with the biggest population in Indonesia. This study was conducted to investigate the characteristics of secondary glaucoma patients at a tertiary hospital in East Java from January 2014 to April 2016.

\section{MATERIALS AND METHODS}

This is retrospective observational study conducted at glaucoma outpatient clinic of a tertiary hospital in Surabaya, East Java from January 2014 to April 2016. Medical records were evaluated, all the cases which had raised IOP (above $21 \mathrm{~mm} \mathrm{Hg}$ ) with or without glaucomatous optic neuropathy with signs of ocular trauma or inflammation or retinal pathology or previous ocular surgery or history of steroid medication were included. The data collected including demographic data, intraocular pressure (IOP), best corrected visual acuity (BCVA), ocular and systemic history. Descriptive statistical analysis using SPSS version 19.0 was used in this study

\section{RESULTS}

Case records of 363 new patients referred to our glaucoma clinic from January 2014 to April 2016 were reviewed. 66 cases diagnosed as secondary glaucoma were found to be eligible for inclusion in the study. The male to female ratio was 1.3:1. Age distribution according to each subtype of secondary glaucoma was depicted in table 1 with among of the cases were occurred at the age of 21-50 years old.

Of the 66 patients having secondary glaucoma, the mean IOP was $28.48 \pm 11.02 \mathrm{mmHg}$ and mean BCVA was $0.10 \pm 0.19$. Most frequent causes of secondary glaucoma were lens factor $30.8 \%$, steroid induced $29.5 \%$, uveitic $20.5 \%$, neovascular $15.4 \%$, and surgical complication $3.8 \%$ (Table 2).

On gonioscopy, $46.2 \%$ had closed angles with the rest $13.4 \%$ had secondary synechial angle closure. The visual acuity at presentation was $\leq 0.1$ in $48.7 \%$ of the cases. Out of $30.8 \%$ lens factor related secondary glaucoma, 5\% resulted from trauma related lens subluxation and the rest from intumescense lens of immature cataract due to late cataract surgery. Among of theses cases, surgery is the treatment of choice to relieve high IOP. Steroid induced glaucoma is the second leading cause of secondary glaucoma, this cases mostly occurred at the adult age with poor BCVA. Despite of IOP lowering drug medication, $42.6 \%$ of cases turned into poor IOP control $>30 \mathrm{mmHg}$.

Table 1. Age distribution of different secondary glaucoma

\begin{tabular}{cccccc}
\hline Age (yo) & Lens factor & Steroid induced & Uveitic & Neovascular & $\begin{array}{c}\text { Surgical } \\
\text { complication }\end{array}$ \\
\hline $11-20$ & - & $5.2 \%$ & - & - & - \\
$21-30$ & $5 \%$ & $63.1 \%$ & $10 \%$ & - & - \\
$31-40$ & - & $31.6 \%$ & $60 \%$ & $14.3 \%$ & $66.7 \%$ \\
$41-50$ & $25 \%$ & $31.6 \%$ & $30 \%$ & $35.7 \%$ & $33.3 \%$ \\
$51-60$ & $40 \%$ & - & - & $21.4 \%$ & - \\
$61-70$ & $30 \%$ & - & - & $28.6 \%$ & - \\
\hline
\end{tabular}

Table 2. Characteristic of different secondary glaucoma from January 2014 to April 2016

\begin{tabular}{lccccc}
\hline $\begin{array}{c}\text { Causes of secondary } \\
\text { glaucoma }\end{array}$ & Number (\%) & Mean age (yo) & Male: female ratio & Mean BCVA & $\begin{array}{c}\text { Baseline IOP > } \\
30 \mathrm{mmHg}\end{array}$ \\
\hline Lens factor & $30.8 \%$ & $56.20 \pm 6.28$ & $12: 8$ & $0.15 \pm 0.10$ & $8.97 \%$ \\
Steroid induced & $29.5 \%$ & $35.83 \pm 1.20$ & $7: 12$ & $0.07 \pm 0.15$ & $8.97 \%$ \\
Uveitic & $20.5 \%$ & $40.81 \pm 5.62$ & $6: 4$ & $0.20 \pm 0.19$ & $7.66 \%$ \\
Neovascular & $15.4 \%$ & $65.70 \pm 5.62$ & $11: 3$ & $0.03 \pm 0.12$ & $14.1 \%$ \\
Surgical complication & $3.8 \%$ & $57.82 \pm 9.98$ & $1: 2$ & $0.05 \pm 0.11$ & $2.56 \%$ \\
TOTAL & $100 \%$ & $51.21 \pm 16.58$ & $37: 29$ & $0.10 \pm 0.19$ & $42.6 \%$ \\
\hline
\end{tabular}




\section{DISCUSSION}

This study revealed that cases of secondary glaucoma in the new and or referred patients at our tertiary hospital were occurred mostly at the range of age 50-60 years. It was related to the most common cause of secondary glaucoma due to senile cataract that occurred at the $>40$ years old of age, as described by Gupta et al (2012). In our study, secondary glaucoma was more common in men than women. It was different with study from Sakata et al (2007) which reported more common cases in women. Yet, Shen et al (2008) showed that there was not any relationship between sex and incidence of glaucoma. This study showed that secondary glaucoma was more occurred in unilateral cases than bilateral cases which in line with study conducted by Gadia et al (2008). However, Bodh et al (2011) showed that cases of glaucoma due to inflammation occurs more in bilateral cases (Gupta et al 2012, Bodh et al 2011, Gadia et al 2008, Shen et al 2008, Sakata et al 2007).

Surprisingly, our study discovered that steroid induced glaucoma is the second leading cause of secondary glaucoma. Steroid induced glaucoma is considered to be a type of secondary open angle glaucoma, caused by increased resistance to the outflow at the level of trabecular meshwork. This cases commonly occurred at the range age 21-30 years $(63.1 \%)$ with mean BCVA $<0.1$ that may be due to easily accesible of steroid eye drop without prescription. As described by Marcus et al (2012) that steroid induced glaucoma are seen most commonly after topical administration. Intraocular pressure rise usually occurs 3-6 weeks following topical steroid use, however may occur earlier. Unlike this study, the elderly population is more susceptible to steroid induced glaucoma as are in children. Moreover, this profile may be due to late presentation to our hospital. Steroid induced glaucoma is often asymptomatic and detected incidentally by an ophthalmologist. Poor IOP control was found in $8.97 \%$ cases despite of IOP lowering medication. Regular follow up with ophthalmologist is necessary to dreaded the complication of glaucoma related to steroid medication. Careful monitoring of all patients in steroid is warranted (Marcus et al 2012, Razeghinejad et al 2012, Nanwani et al 2015).

This study discovered other causes of secondary glaucoma including uveitic, angle neovascularization, and glaucoma related to surgical complication. Heinz et al (2009) described that IOP increased in $8.8 \%$ cases of uveitic patients in the middle age as showed in our study. In this study, only $7.6 \%$ uveitic glaucoma cases had poor IOP control, unlike study conducted by Heinz et al (2009) that showed 24\% patients with poor IOP control. Our study showed that all of the cases of neovascular glaucoma were related to high risk proliferative diabetic retinopathy with poor glycemic control. This cases account for $15.4 \%$ which presented with BCVA <0.1, as showed in study conducted by $\mathrm{Al}$ Bahlal et (2017) al that $76 \%$ patients with neovascular glaucoma presented with BCVA $<0.1$. The case of neovascular glaucoma was more commonly occurred in the age range 31-40 years in man, in accordance with study by Al Bahlal et al (Al Bahlal et al 2017). The least cause of secondary glaucoma in our study was related to surgical complication, mainly vitrectomy surgery with silicon oil migration to anterior chamber. Limitations of this study are the difficulties to access the medical records and single evaluation at the first presentation of new and or referred patients.

\section{CONCLUSION}

Secondary glaucoma patients occurred more in men than in women at the age range 51-60 years. Secondary glaucoma is commonly unilateral with intraocular pressure $\geq 30 \mathrm{mmHg}$. The most common etiology of these disorders is lens induced glaucoma. Different with other study, steroid induced glaucoma is the second leading cause of glaucoma in our study. Secondary glaucoma warrants early detection and treatment to preserve optic nerve damage.

\section{REFERENCES}

Al Bahlal A, Khandekar R, Al Rubaie K, Alzahim T, Edward D, Kozak I (2017). Changing epidemiology of neovascular glaucoma from 2002 to 2012 at King Khaled Eye Specialist Hospital, Saudi Arabia. Indian journal of ophthalmology 65, 969-973

Bodh S, Kumar V, Raina U, Ghosh B, Thakar M (2011). Inflammatory glaucoma. Oman J Ophthalmol 4, 3-9

Congdon N, Klaver C, Klein R, Munoz B, Friedman DS (2004). Causes and prevalence of visual impairment among adults in the United States. Arch Ophthalmol $122,477-85$

Gadia, Sihota, Dada, Gupta (2008). Current profile of secondary glaucomas. Indian Journal of Ophthalmology 56, 285-289

Gupta P, Bhagotra S, Prakash S (2012). Pattern and visual outcome in lens induced glaucoma. Science Journal of Medical Education and Research 14,181-4

Heinz C, Koch J, Imhoff B, Heiligenhaus A (2009). Prevalence of uveitic secondary glaucoma and success of nonsurgical treatment in adults and children in a tertiary referral center. Ocular immunology and inflammation 17, 243-248 
Marcus M, Muskens R, Ramdas W, Wolf R, De Jong P, Vingerling J, Hofman A (2012). Corticosteroids and open angle glaucoma in the elderly: a populationbased cohort study. Drugs aging 29, 963-970

Masompour MB, Nowroozzadeh MH, Razeghinejad MR (2016). Current and future techniques in wound healing modulation after glaucoma filtering surgeries. The Open Ophthalmology Journal 10, 68-85

Nanwani, Dev, Shilpa, Ganesh (2015). Profile of secondary glaucoma cases in a tertiary eye care centre. IOSR Journal of dental \& medical sciences 14, 53-58

Ramakrishnan R, Nirmalan P, Krishnadas R, Thulasiraj $R$ (2004). Glaucoma in a rural population of southern India: The Aravind comprehensive eye survey. Ophthalmology111, 331.

Razeghinejad M, Katz L (2012). Steroid-induced iatrogenic glaucoma. Ophthalmic Res 42, 66-80

Rifqah E, Gustianty E, Prajitno I (2017). One year data of new secondary glaucoma patients at top referral eye hospital in Indonesia. Althea medical journal 4,163166

Sakata K, Sakata LM, Sakata VM, Santini C, Hopker LM, Bernardes R (2007). Prevalence of glaucoma in a South Brazilian population: Projeto Glaucoma. Invest Ophthalmol Vis Sci48,4974-9

Shen S, Wong T, Foster P, Loo J, Rosman M (2008). The prevalence and types of glaucoma in Malay people: the Singapore Malay eye study. Invest Ophthalmol Vis Sci 49,3846-51

Tham, Li, Wong, et al (2014). Global prevalence of glaucoma and projection of glaucoma burden through 2040. American Academy of Ophthalmology Journal 121, 2081-2089

Wang Y, Xu L, Yang H, Jonas JB (2010). Prevalence of glaucoma in North China: the Beijing Eye Study. Am J Ophthalmol150, 917-24

Yamanaka O, Izutani A, Tomoyose K, Reinach PS (2015). Pathobiology of wound healing after glaucoma filtration surgery. BMC Ophthalmology 15, 1-9 